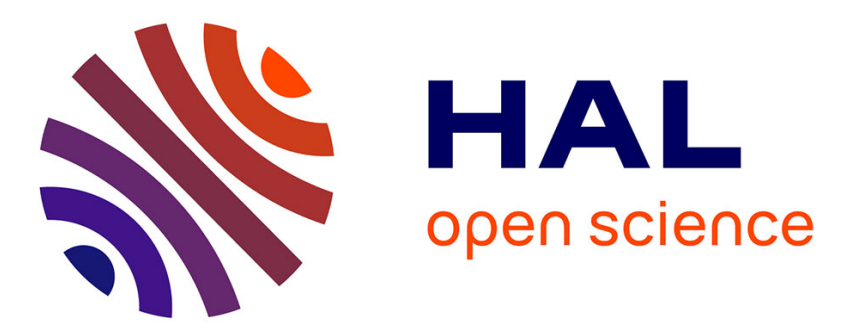

\title{
Erosion rates and sediment budgets in vineyards at 1-m resolution based on stock unearthing (Burgundy, France).
}

Jérôme Antoine Brenot, Amélie Quiquerez, Christophe Petit, Jean-Pierre Garcia

\section{To cite this version:}

Jérôme Antoine Brenot, Amélie Quiquerez, Christophe Petit, Jean-Pierre Garcia. Erosion rates and sediment budgets in vineyards at 1-m resolution based on stock unearthing (Burgundy, France).. Geomorphology, 2008, 100 (3-4), pp.345-355. 10.1016/j.geomorph.2008.01.005 . hal-00315405

\section{HAL Id: hal-00315405 https://hal.science/hal-00315405}

Submitted on 11 May 2020

HAL is a multi-disciplinary open access archive for the deposit and dissemination of scientific research documents, whether they are published or not. The documents may come from teaching and research institutions in France or abroad, or from public or private research centers.
L'archive ouverte pluridisciplinaire HAL, est destinée au dépôt et à la diffusion de documents scientifiques de niveau recherche, publiés ou non, émanant des établissements d'enseignement et de recherche français ou étrangers, des laboratoires publics ou privés. 


\title{
Erosion rates and sediment budgets in vineyards at 1-m resolution based on stock unearthing (Burgundy, France)
}

\author{
Jérôme Brenot $^{\mathrm{a}, *}$, Amélie Quiquerez ${ }^{\mathrm{a}}$, Christophe Petit ${ }^{\mathrm{b}}$, Jean-Pierre Garcia ${ }^{\mathrm{b}}$ \\ ${ }^{\mathrm{a}}$ UMR CNRS 5561 Biogéosciences, Université de Bourgogne, 6, Boulevard Gabriel, 21000 Dijon, France \\ ${ }^{\mathrm{b}}$ UMR CNRS 5594 Archéologie, Cultures et Sociétés, Université de Bourgogne, 6, Boulevard Gabriel, 21000 Dijon, France
}

Received 8 November 2006; received in revised form 30 December 2007; accepted 5 January 2008

Available online 16 January 2008

\begin{abstract}
A new and simple method is developed to efficiently quantify erosion and deposition rates based on stock unearthing measurements. This is applicable to spatial scales ranging from plot to hillslopes, and to time scales ranging from single hydrologic events to centennial scales. The method is applied to a plot area on vineyard hillslopes in Burgundy (Monthélie, France), with measurement of 4328 vine plants. A sediment budget established at the plot scale shows a mean soil lowering of $3.44 \pm 1 \mathrm{~cm}$ over 20 years, involving a minimal erosion rate of $1.7 \pm 0.5 \mathrm{~mm} \mathrm{yr}^{-1}$. Locally, erosion rates can reach up to $8.2 \pm 0.5 \mathrm{~mm} \mathrm{yr}^{-1}$.

This approach allows the sediment redistribution to be mapped and analyzed at $1-\mathrm{m}$ resolution. It provides novel insights into the characterization of erosion patterns on pluri-decennial scales and into the analysis of spatial distribution of erosion processes on cultivated hillslopes. (C)
\end{abstract}

Keywords: Soil erosion; Vineyard; Sediment flux quantification; Spatially distributed erosion patterns; Burgundy

\section{Introduction}

The quantification of sediment flux at various temporal and spatial frames is crucial to the understanding of how the Earth's surface system operates (Einsele and Hinderer, 1997). In agricultural lands, such quantification is in fact essential to monitor and predict the extent of soil degradation, with the goal of improving soil management and soil conservation planning (Wischmeier and Smith, 1978; Goudie, 2005; Morgan, 2005; Boardman and Poesen, 2006). Sediment loss has critical consequences on soil conservation in terms of quantity because soil is removed, as well as in terms of quality due to nutrient losses. Irreversible soil degradation can lead to serious environmental, economic and social damage (Fournier, 1972; Le Bissonnais et al., 2002), making sediment flux measurement a major source of information for ensuring sustainable agriculture.

\footnotetext{
* Corresponding author. Present address: UMR CNRS-UPS 8148 IDES, Université de Paris-Sud 11, Département des Sciences de la Terre, Bât. 504, 91405 Orsay Cedex, France. Tel.: +33 1 69156747; fax: +33 169154882.

E-mail address: jerome.brenot@u-psud.fr (J. Brenot).0

doi:10.1016/j.geomorph.2008.01.005
}

Conventional measurement methods so far employed to infer sediment flux are extremely sensitive to the time scale involved, e.g. from a single rainstorm to several decades, and to their associated spatial scales, e.g. from plots to regional basins (Fig. 1). Flux-based methods (e.g. Verstraeten and Poesen, 2001), surface elevation change-based methods (e.g. MartínezCasasnovas et al., 2005), and geochemical methods (e.g. Quine and Walling, 1991; Kirchner et al., 2001; Van Der Perk and Jetten, 2006) are the most frequently used.

The principle of flux-based methods is based on the direct gauging of river load in small to large drainage basins (Meade, 1988; Einsele and Hinderer, 1997). Measurements are converted into erosion rates, but at best only for the last hundred years (Verstraeten and Poesen, 2001). For longer periods, i.e. centennial to millennial time scales, erosion rates are estimated from the quantification of sediment volume preserved in lakes or other similar reservoirs (Einsele and Hinderer, 1997; Buoncristiani et al., 2002). Whatever the time scale involved, such methods only provide spatially averaged rates representative of the whole catchment, since the sediment production area is assumed to be homogeneous at the drainage basin scale. Other limits of the method lie in the difficulty of obtaining 
sufficient data. Sediment budgets may be biased and commonly underestimated because of temporal variations in sediment delivery (Kirchner et al., 2001), poor localization of sediment sources (Wainwright et al., 2003; Rommens et al., 2006), and sediment trapping upstream within the catchment area (Sirvent et al., 1997; Verstraeten and Poesen, 2001).

Estimates of short-term erosion rates may be derived from "surface elevation change-based" methods, which measure the topographic evolution of hillslopes through time. For example, surface lowering or aggradation rates are quantified from DEM or profilometer analysis (Sirvent et al., 1997; MartínezCasasnovas et al., 2002, 2005). Spatially distributed data can be acquired, but only for very specific spatio-temporal scales, e.g. for a single rainstorm event within experimental plots (Martínez-Casasnovas et al., 2005), or for an annual time scale over hillslopes (Vandaele et al., 1996; Sirvent et al., 1997). Other problems spring from the installation and calibration of unstandardized measurement devices, potentially influencing the accuracy of the data (Wainwright et al, 2003; Stroosnijder, 2005; Boix-Fayos et al., 2006).

Over the last few decades, geochemical methods have been widely used to assess erosion rates in for a large range of time scales. Radio-nuclide proxies such as ${ }^{137} \mathrm{Cs}$ have increasingly been used to determine erosion rates at a decennial time scale (Quine and Walling, 1991; Ritchie et al., 2005). In-situ produced cosmogenic nuclide methods are preferred for estimations at $10^{3}$ to $10^{5} \mathrm{yr}$ time scales (Lal, 1991; Hewawasam et al., 2003), whereas long-term erosion rates (1-10 Myr) are inferred from fission-track thermochronology methods or other radiometric dating (Sweetkind and Blackwell, 1989; Kirchner et al., 2001). Spatial scales range from the agricultural plot for ${ }^{137} \mathrm{Cs}$ up to the basin scale for cosmogenic nuclides. Except for very specific cases such as ${ }^{137} \mathrm{Cs}$, where it is possible to trace sediment movement along cross-sections (Hilfiker and Dominik, 1989; Quine and Walling, 1991; Ritchie et al., 2005), such methods only provide whole-catchment erosion rates due to the scarcity of intrasite sample data for technical or financial reasons (Stroosnijder, 2005).

Temporally-and spatially-distributed data may also be inferred from the identification of bio-markers by using dendrogeomorphology methods for decennial to millenium time scales (Eardley and Viavant, 1967; LaMarche, 1968; Alestalo, 1971; Dunne et al., 1978; Carrara and Carroll, 1979; Danzer, 1996). The dendrogeomorphic approach uses tree ring characteristics to estimate the rates of soil erosion (Carrara and Carroll, 1979; Gärtner et al., 2001; Bodoque et al., 2005; Gärtner, 2007), accumulation rates associated with flooding (Martens, 1993) or mass movements (Strunk, 1997). Aggradation or degradation processes are directly inferred from the position of the root collar, considered as a fixed spatial reference relative to the current ground surface.

This paper proposes a new method that uses stock unearthing as a soil loss marker for assessing erosion rates at 1-m resolution, over spatial scales ranging from the plot to hillslopes, and from hydrologic events to centennial timescales (Fig. 1). A soil loss quantification was performed at a 20 -yr time scale and on a 0.45 ha plot in Burgundian vineyards, corresponding to a full data set of 4328 vines. Although having a modest extension over the earth surface, i.e. of about $8 \times 10^{6}$ ha, vineyards have been particularly valued in the

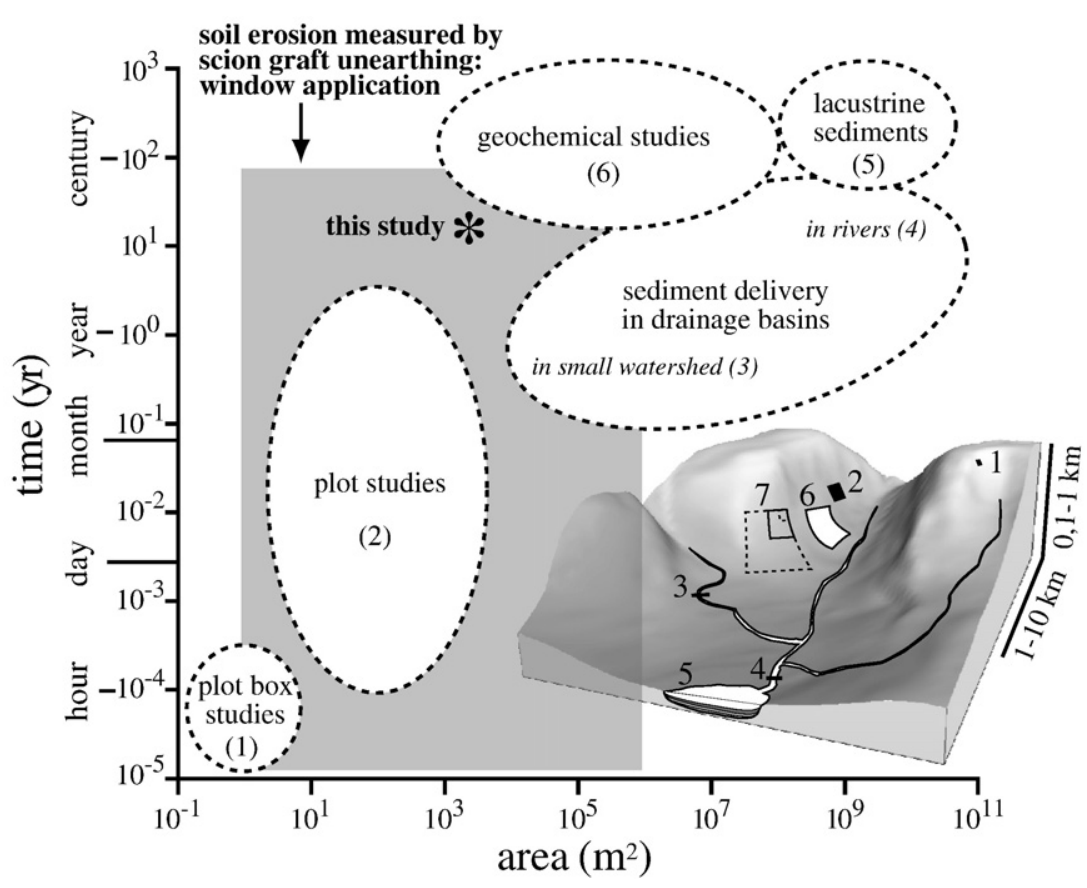

Fig. 1. Methods used to quantify soil erosion, according to their spatio-temporal scales, modified after Verstraeten and Poesen (2001). 1) Verstraeten and Poesen (2001); 2) Buoncristiani et al. (2002); 3) Kirchner et al. (2001); 4) Martínez-Casasnovas et al. (2005); 5) Quine and Walling (1991); 6) Battany and Grismer (2000); 7) this study. The SUM method can be applied on a temporal window ranging from a hydrological event up to a century, and with a spatial window from square meters to hillslopes. 
literature as a land-use context highly susceptible to erosion with substantial soil losses, as compared to other types of agricultural land, which therefore constitute a situation where soil sustainability is threatened (Kosmas et al., 1997; Le Bissonnais et al., 2002; Krause et al., 2003; Boardman and Poesen, 2006; Hooke, 2006; Brenot et al., 2006).

\section{Study area}

The method was applied to a plot on the hillslopes of Monthélie (Fig. 2), in the Côtes-de-Beaune area (Burgundy, France). The hillslopes, formed as a result of the Bressan rifting, constitute the eastern border of the Burgundian plateau. Vinegrowing has developed on a fault scarp since the Roman times and Middle-Ages (Dion, 1959). The landscape is characterized by a vine monoculture where the parcellar limits, i.e. walls and paths, are the only discontinuities along the hillslopes since the Phylloxera crisis at the end of the 19th century, and since the 20 th century mechanization. These hillslopes are covered by a silty-clayey calcosol that develops on Jurassic marls, where vines are cultivated.

The studied plot, which is located on the west side of a northoriented valley (Fig. 2), is $144 \mathrm{~m}$ long and $33 \mathrm{~m}$ wide. A digital elevation model from a topographic survey with a laser theodolite shows slopes from $8^{\circ}$ to $16^{\circ}$. The vine stocks are planted parallel to the slope which give favorable conditions for sediment exportation. Bare interrows with chemical weeding, slope-oriented rows, and very superficial tillage occurring one or twice a year are the dominant agricultural practices in Burgundy. Such conditions occur in the plot selected for the study.

\section{Methodology}

\subsection{Principles}

The principle of soil loss measurement, similar to that used by dendrogeomorphology methods, is based on the unearthing of the stock located on the vine plants (Stock Unearthing Measurement, hereafter abbreviated as "SUM"), considered as a passive marker of soil surface vertical displacement since the year of plantation (Fig. 3). Grafted vine plant anatomy and particular plantation practices in Burgundian vineyards motivated the development of such a method.

The anatomy of grafted vines can be divided into two components (Fig. 3A): "American" stock (a vine shoot section) with underground roots, and aerial scion (especially Pinot Noir and Chardonnay in Burgundy). The limit between the two components corresponds to the graft union, materialized by net stock diameter and bark texture variation. The use of a specific stock species, developed by the end of the 19th century after the Phylloxera crises (Garrier, 1989), involves a natural protection of scions from Phylloxera by grafting scion species on a generic stock. Plantation practice, regimented by regional by-laws, demands that the scion-graft union be located $1 \mathrm{~cm}$ above the soil surface when vines are planted (Galet, 1993), in order to prevent contact between the scion and the soil. During vine's growth, the stock develops its own roots that are concentrated at the lower part of the stock (Fig. 3A), while vine shoots develop from the scion.

The SUM method is based on the assumption that the stock exposure reflects the dynamics of soil aggradation/ablation, considering the scion-graft limit to be a marker of the initial
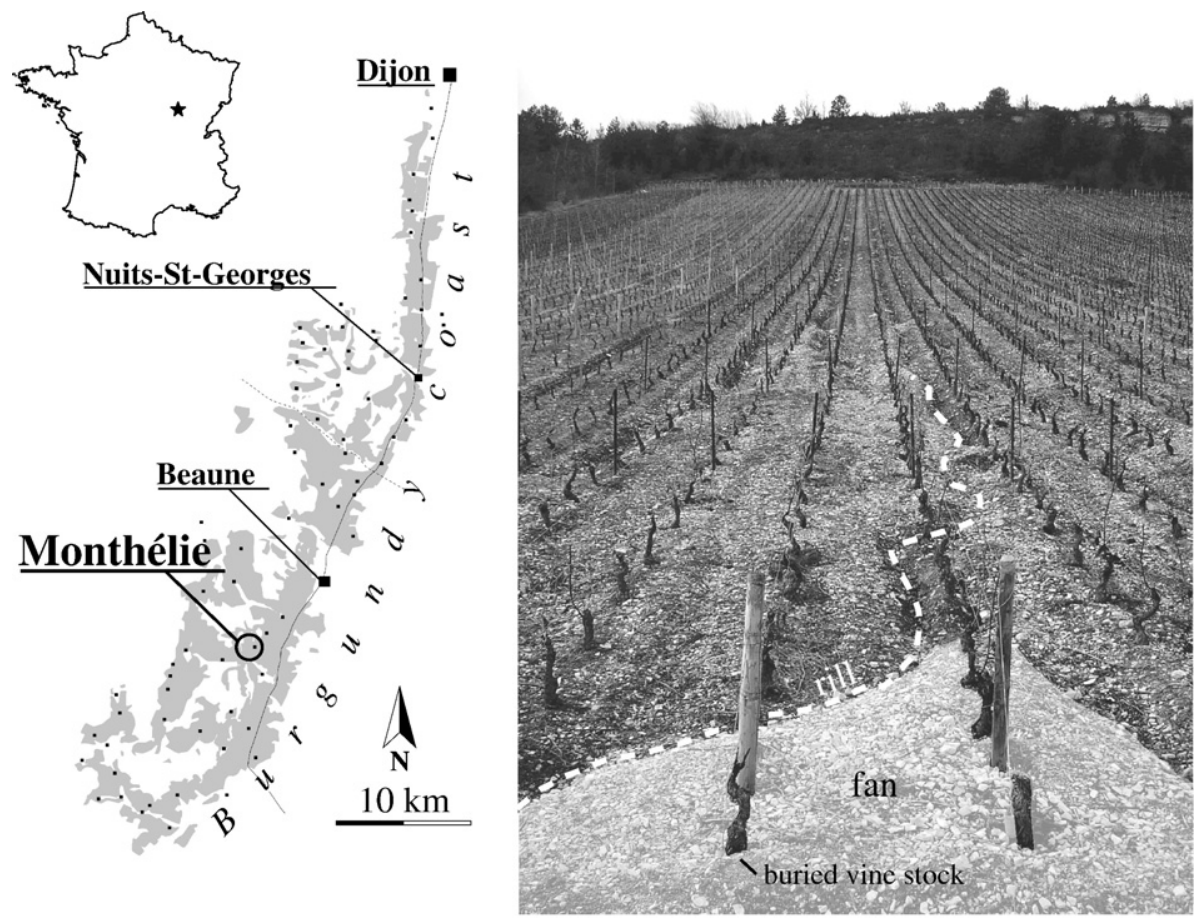

Fig. 2. Location and photograph of the studied plot in the Burgundian vineyards. Monthélie is located in the "Côtes-de-Beaune" area. As shown in the photograph, rills grow preferentially within the interrow area, and fans develop at the toe of the plot. 
A
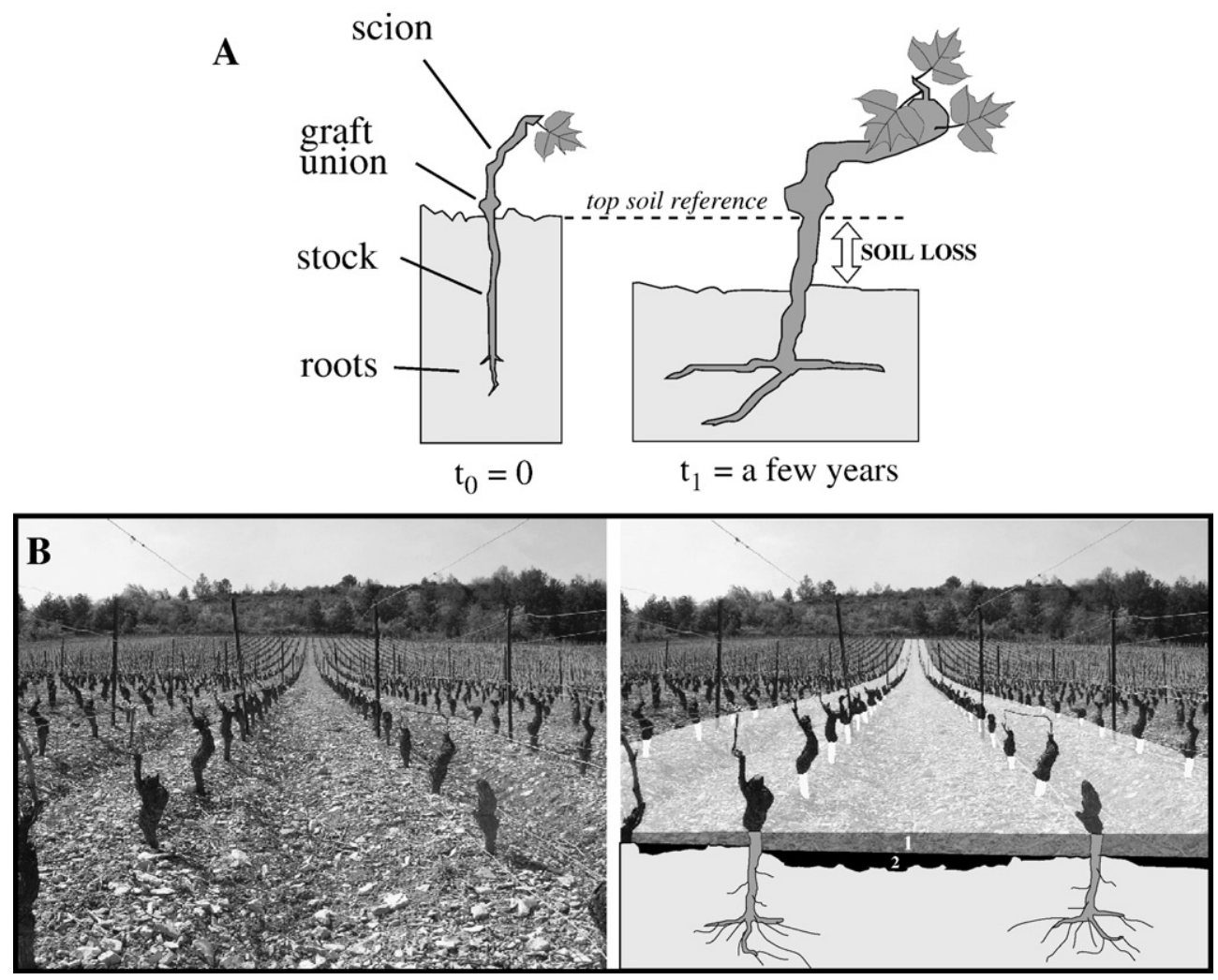

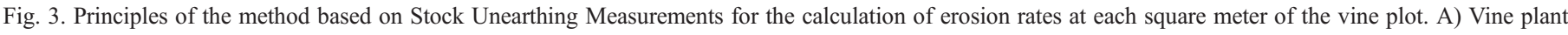

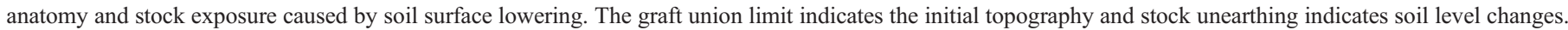

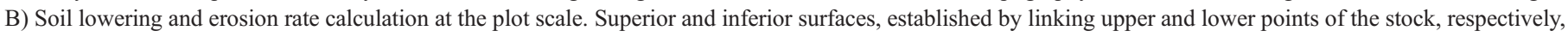
allow us to calculate an eroded volume (volume 1). The interrow roughness (volume 2) is not included in the soil loss calculation.

topography (Fig. 3B). Alternatively, any vertical displacement of the scion-graft level during vine's life involves a bias in unearthing measurements by suggesting an incorrect initial topography (Fig. 3A). The natural uplift of the woody plant (LaMarche, 1968) due to root growth has been verified by the observations of stock unearthing in non-eroded vine plots that are located in the Burgundian plain (in Monthélie). The hypothesis that the graft level is lifted upwards has been rejected because all scion-graft levels are located close to the ground surface, with a mean stock exposure inferior or equal to $1 \mathrm{~cm}$, in conformity with the legal requirements for plantation. These observations suggest that the cuttings of the germination points (both upper and lower parts of the stock) by grafted scion makers prevent any vertical stock growth, while the scion will grow in all directions. Consequently, a vertical increase of the stock, even if present, is minimal and effectively negligible.

Conversely, a downward shifting of the graft limit is induced by a scion versus stock growth difference (Fig. 4). Vine plant sections show that the visible graft limit linearly decreases with

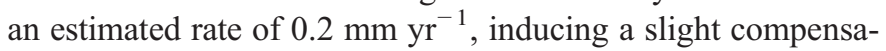
tion of the stock exposure. This rate is based on our measurements from vines $(n=7)$ with different ages in which the shifting of the graft limit was clearly visible. This natural lowering implicates that SUM underestimates the true soil lowering, taking the visible scion-graft level as a reference and not the internal level. Soil lowering rates, calculated from SUM, have thus to be corrected by considering scion-graft lowering rates.
Therefore, the graft limit can be considered as a spatial and temporal reference, similar to the tree root collar whose position below or above the surface has been proven to be a good estimate of the soil aggradation or ablation rates (LaMarche, 1968; Alestalo, 1971; Carrara and Carroll, 1979). The spatial distribution of vine stocks in the Burgundian vineyards

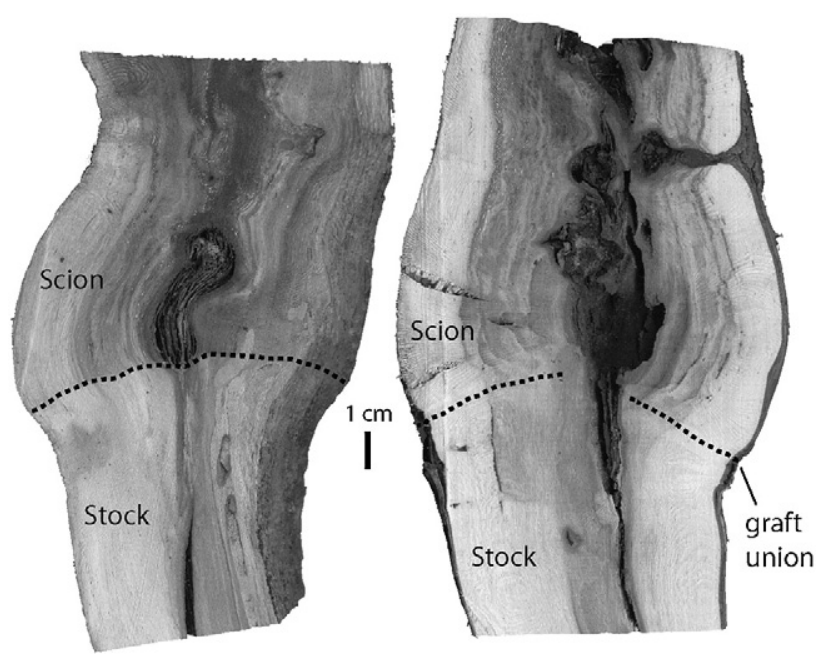

Fig. 4. Examples of vine plant section at the scion-graft level. The dashed line represents the graft union lowering due to the growth difference between the scion and the stock, with a rate estimated at $0.2 \mathrm{~mm} \mathrm{yr}^{-1}$. The vines are 45 (left) and 60 (right) years old. Note the "proto-scion" inside the scions. 

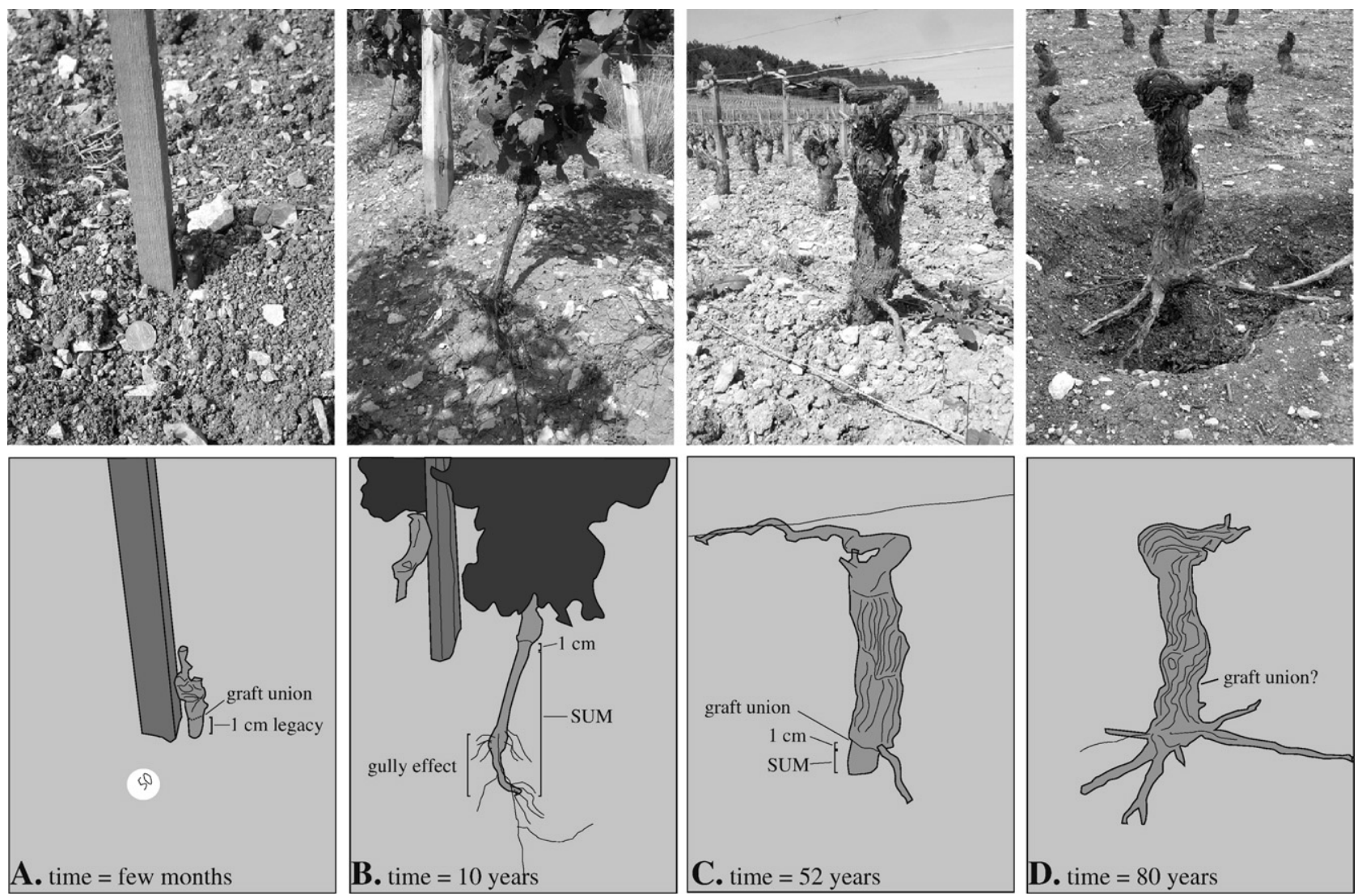

Fig. 5. Illustrations of different vine unearthing examples in Burgundy. A) Vine plant just after the plantation. The graft union level is located at $1 \mathrm{~cm}$ above the soil surface (near Monthélie, spring 2006). B) 10-year old vine plant in a recently formed gully (near Couchey, summer 2005). C) Growth of a root from the scion, which indicates that the graft union was buried (near Monthélie, spring 2006). D) Old vine plant, excavated for removal. The bark aging erases the graft union limit (near Vosne-Romanée, winter 2006).

(plantation legislation imposes a density of 10,000 vines per hectare) allows the quantification of erosion at various spatial scales, from $\mathrm{m}^{2}$ to the hillslope scale, without any resolution variation. The upper limit in the temporal application window corresponds to the maximum possible age of vine stocks (Figs. 1 and 5), due to bark aging and vine plant renewal by vine growers ( 100 years). The lower limit is that of a hydrologic event able to remove sediment from hillslopes (a few hours), in the specific case where a reference state of SUM values was assessed prior to the rainstorm (Fig. 6).

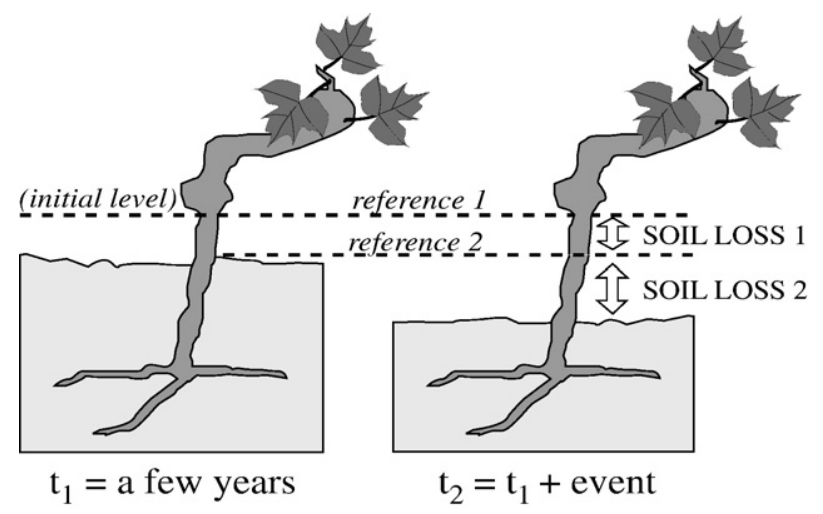

Fig. 6. Principle of the SUM method applied to the event scale.

\subsection{Soil loss quantification}

In this study, the quantification of soil losses is performed at two spatial scales of interest. At the micro-scale $\left(\mathrm{m}^{2}\right)$, soil lowering rates are estimated from stock exposure for each vine, and then for each row area of the plot. However, as suggested in Fig. 3B, these rates can not be extrapolated to the interrow areas. Considering a planar initial surface at the plantation time, the current erosion surface is mainly characterized by the presence of a slope-oriented roughness. This is illustrated by the spatial alternation of interrows more deeply eroded than rows. The origin of this differential incision should be found in the differential land-use that occurs between these areas, with different vegetation covers due to vines, and different soil properties, e.g. a lower infiltration rate due to soil compaction by straddle-tractor traffic along interrows. During intense rainfall events, rill initiation and incisions are confined to interrow areas (Quiquerez et al., in press). Thus, the slope-oriented roughness volume seems to be a result of an increasing soil compaction over time, and of an incomplete deletion of ephemeral rills by tillage operations. This lasting roughness (Fig. 3B) represents a favorable topography for water concentration in interrow areas.

At the macro-scale (plot), the calculation of the eroded volume should be equal to the addition of the interrow volume (roughness) and the row volume (SUM), but the interrow 
volume was not considered at the plot scale, due to a lack of quantitative and qualitative data (Fig. 3B). The relative contribution of soil compaction in the roughness is uncertain. Moreover, the roughness is mainly dependent on (i) the tillage operations that counterbalance rill incisions by transporting sediment from row to interrow areas, and (ii) rill infilling with sediment input by vine growers (Quiquerez et al., in press). Consequently, the amount of erosion in this study is taken as the volume contained between an initial topography and the surface established by linking two adjacent stocks (Fig. 3B), located at the top of the vine rows. In order to minimize this quantitative bias, SUM has been performed when the interrow roughness is minimal, corresponding to a tilled surface after the grape harvesting season: data have been collected during the winter season.

If we accept the assumption that these rates and associated volumes are minimal, the SUM application permits the calculation of erosion rates for each square meter of the vine plot.

\section{Results}

\subsection{Measurement uncertainties and field protocol}

The robustness of the SUM procedure was tested under several scenarios of anthropogenic influence. At first, human plantation error has been estimated by SUM on recently planted vines on the Monthélie hillslopes. The measurements confirmed that the $1 \mathrm{~cm}$ recommendation (the normalized distance between soil and graft level for the plantation) is generally followed $(n=117$; median $=1 \mathrm{~cm} ; \mathrm{SD}=1.3 \mathrm{~cm})$. To allow for maximal human error at the time of planting, an error margin of $\pm 1 \mathrm{~cm}$ was added to SUM. In the studied plot, the measurements were systematically done on the downslope side of the vine plants. In order to estimate the measurement error, measurements were done twice on each of 500 stocks, and a correlation of $r^{2}=0.94$ was found. Thus, for each stock, the distance between the scion-graft limit and the current soil surface was observed based on a single measurement, given the strong correlation of replicate measurements. SUM values are expressed in centimeters, negative for ablation and positive for aggradation.

Secondly, soil compaction effects, which could influence the stock exposure, have been assessed by SUM on two on-eroded plots, located in Monthélie over horizontal topography. Measurements show that the mean SUM is equal to $-0.53 \mathrm{~cm}$ $(n=200 ;$ median $=0 \mathrm{~cm} ; \mathrm{SD}=1.2 \mathrm{~cm})$ and $-0.9 \mathrm{~cm}(n=100$; median $=-1 \mathrm{~cm} ; \mathrm{SD}=1.5 \mathrm{~cm}$ ) for vines with ages of 60 and 35 years, respectively. This observation also confirms the hypothesis that the stock does not grow vertically after its plantation, as expected.

Finally, SUM is adjusted to take into account both the plantation recommendation $(+1 \mathrm{~cm})$ and plantation error $( \pm 1 \mathrm{~cm})$. Erosion rates are calculated by dividing the SUM by the age of the vines, with a correction for the natural decrease of the scion-graft level $\left(0.2 \mathrm{~mm} \mathrm{yr}^{-1}\right)$ supposed to be uniform for all vines of the studied plot. For example, a given exposure of $11 \mathrm{~cm}$ on a 20 years old vine corresponds to a SUM equal to $-10 \pm 1 \mathrm{~cm}$, and to an erosion rate of $5.2 \pm 0.5 \mathrm{~mm} \mathrm{yr}^{-1}$.
The full data set corresponds to 4328 vines over a surface of $4475 \mathrm{~m}^{2}$. All the vines were planted 20 years before sampling, and approximately 150 vine plants are missing.

\subsection{Soil loss rates}

Fig. 7 shows the SUM map obtained, representing topographic change over the last 20 years. Each computed value, ranging from

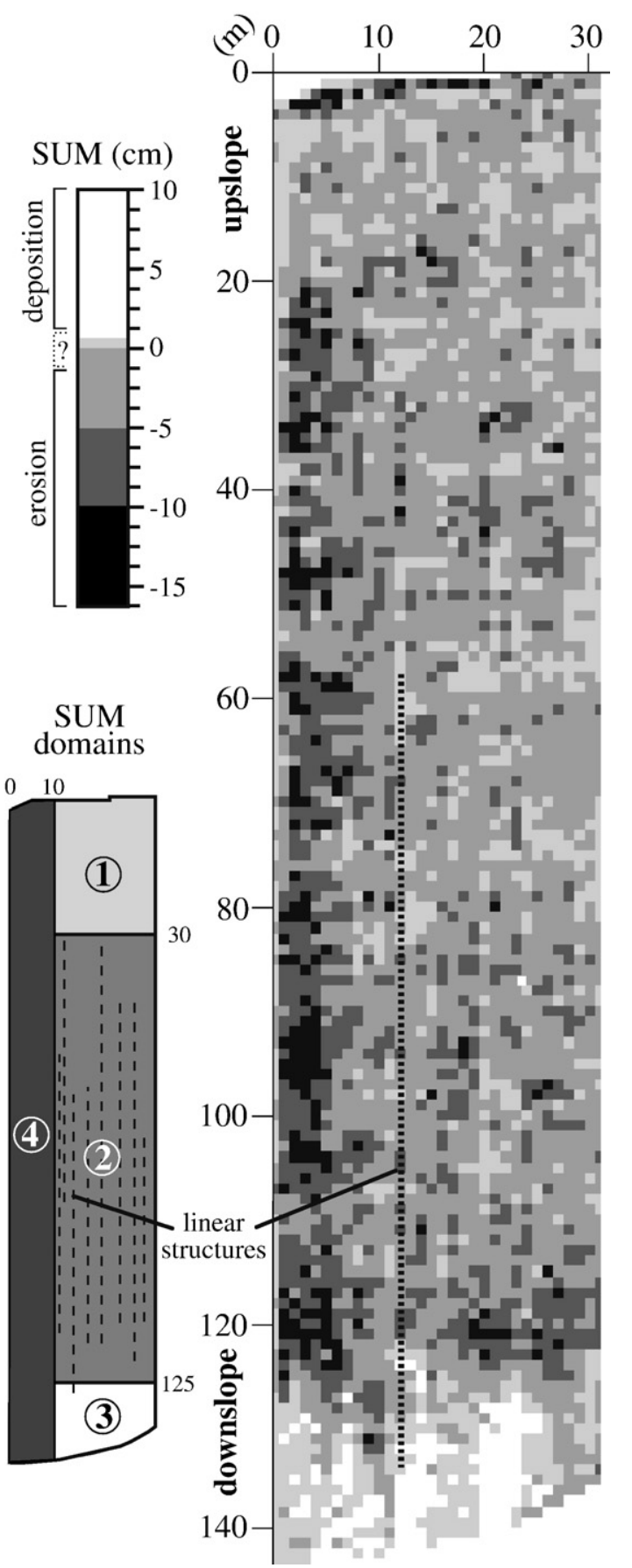

Fig. 7. SUM map of the entire studied plot. Gray pixels indicate SUM values $<0 \mathrm{~cm}$; white pixels indicate SUM values $>0 \mathrm{~cm}$. In the left-bottom corner, the SUM map is divided into four sedimentary domains, as described in the text. 


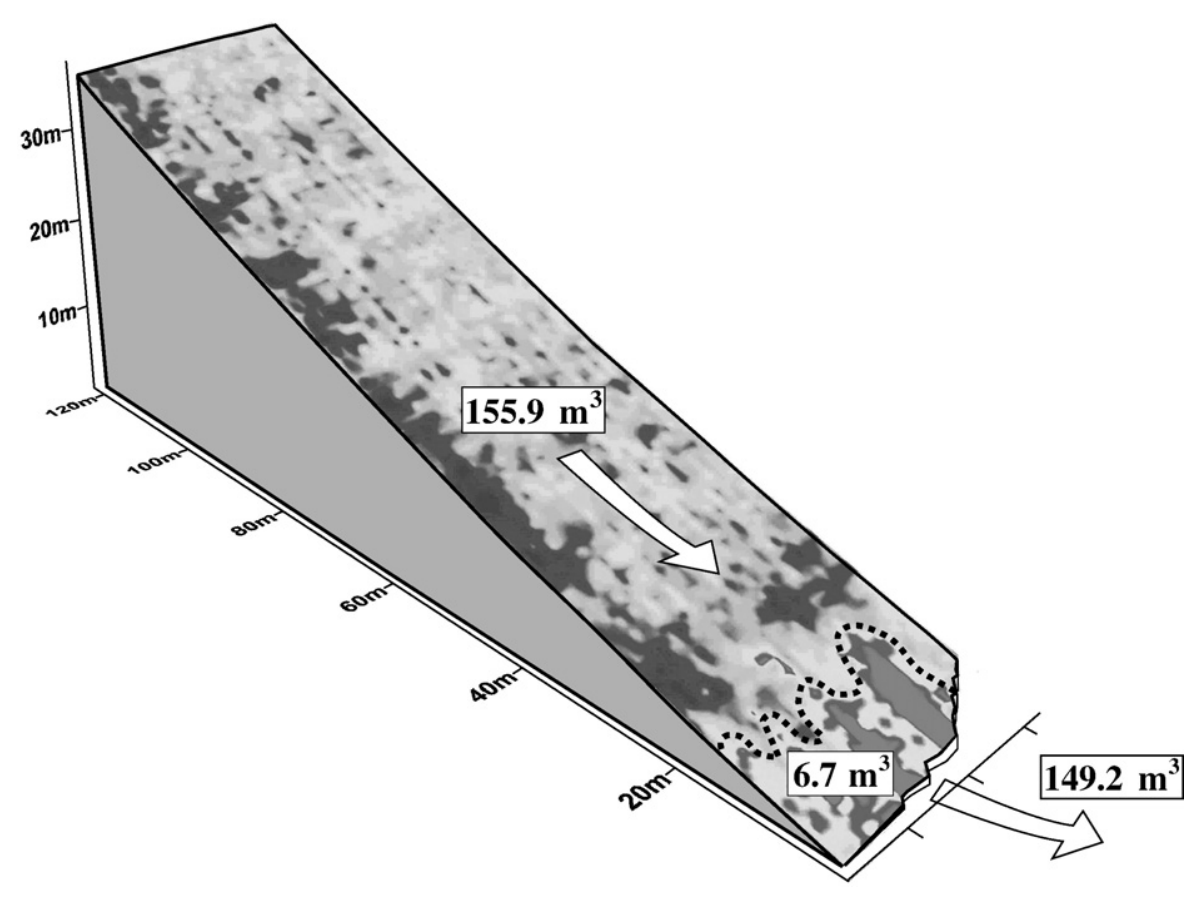

Fig. 8. SUM map overlaid on the DEM. Minimal soil loss is estimated at $149.2 \mathrm{~m}^{3}$, corresponding to a mean soil lowering rate of $1.7 \mathrm{~mm} \mathrm{yr}^{-1}$.

$-16 \mathrm{~cm}$ to $+10 \mathrm{~cm}$, corresponds to one measurement per meter square.

At first, a sediment budget was established at the plot scale by calculating volumes of sediment located above and below the original reference surface (Figs. 3 and 8): the eroded volume is estimated at $155.9 \mathrm{~m}^{3}$, and the deposition volume is $6.7 \mathrm{~m}^{3}$, which corresponds to a net exported volume at the outlet boundary of $149.2 \mathrm{~m}^{3}$ (Fig. 8; Table 1). This soil loss volume was divided by the surface area and vine age (20 years) to calculate a mean topographic lowering of $3.44 \pm 1 \mathrm{~cm}$, and a mean erosion rate of $1.7 \pm 0.5 \mathrm{~mm} \mathrm{yr}^{-1}$. Erosion rates may locally reach $8.2 \pm 0.5 \mathrm{~mm}$ $\mathrm{yr}^{-1}$, whereas accumulation rates reach, maximum at $5.3 \pm 0.5 \mathrm{~mm}$ $\mathrm{yr}^{-1}$. Net soil loss is $23 \pm 9 \mathrm{t} \mathrm{ha}^{-1} \mathrm{yr}^{-1}$ for a bulk density ranging from 1.25 to 1.5 .

This result, obtained at the plot scale, is consistent with previously calculated erosion rates for vineyards (Kosmas et al., 1997; Martínez-Casasnovas et al., 2002; Hooke, 2006) where erosion rates may reach several tons per hectare per year (Table 2), corresponding to a mean soil lowering rate higher than $1 \mathrm{~mm} \mathrm{yr}^{-1}$.

\subsection{Erosion maps}

Soil surface lowering is observed over $75 \%$ of the plot surface, whereas aggradation is observed over 5\% (Fig. 7). SUM equal to the original plantation state, i.e. located between $+/-1 \mathrm{~cm}$ relative to the reference surface, represents $20 \%$ of the entire surface. Four spatial domains are identified (Fig. 7 and Table 1): (1) an upper slope domain, from 0 to $30 \mathrm{~m}$ from the upslope boundary, displaying a relatively low erosion rate, i.e. $1.5 \mathrm{~mm} \mathrm{yr}^{-1}$, almost constant throughout this domain; (2) a mid-slope domain from 30 to $120 \mathrm{~m}$, where maximum SUM values are reached, characterized by increasing SUM in a downslope direction. All SUM values are negative or zero $(+/-1 \mathrm{~cm})$. The erosion rate locally reaches $8.2 \mathrm{~mm} \mathrm{yr}^{-1}$; (3) a lower slope domain, covering the surface between the $120-\mathrm{m}$ position and the downslope boundary, characterized by a soil-aggrading area where the graft union may be covered; and (4) an intensively eroded area defined by the first ten rows at the left boundary. This area represents $42 \%$ of the missing material but only $27 \%$ of the plot surface. Especially within this final domain, it is possible to

Table 1

SUM values, erosion rates, mean lowering and eroded volumes in the four domains of the studied plot

\begin{tabular}{|c|c|c|c|c|c|c|c|c|c|}
\hline \multirow{2}{*}{$\begin{array}{l}\text { Distance from } \\
\text { uppermost } \\
\text { slope }(\mathrm{m})\end{array}$} & \multicolumn{2}{|c|}{ SUM (cm) } & \multirow[t]{2}{*}{$\begin{array}{l}\text { Mean surface } \\
\text { change }(\mathrm{cm})\end{array}$} & \multicolumn{3}{|c|}{$\begin{array}{l}\text { Topographic change rate } \\
\left(\mathrm{mm} \mathrm{yr}^{-1}\right)\end{array}$} & \multirow[t]{2}{*}{$\begin{array}{l}\text { Domain area } \\
\left(\mathrm{m}^{2}\right)\end{array}$} & \multicolumn{2}{|c|}{$\begin{array}{l}\text { Volume of topographic } \\
\text { change }\left(\mathrm{m}^{3}\right)\end{array}$} \\
\hline & Max & Min & & Max & Min & Mean & & Deposition & Erosion \\
\hline $1-30$ & +1 & -16 & -3.05 & +0.3 & -8.2 & -1.5 & 825 & 0.6 & 25.8 \\
\hline $31-125$ & +1 & -16 & -4.11 & +0.3 & -8.2 & -2.0 & 3008 & 0.6 & 124.2 \\
\hline $126-145$ & +11 & -13 & -0.08 & +5.3 & -6.7 & -0.0 & 495 & 5.5 & 5.9 \\
\hline Total plot & +11 & -16 & -3.44 & +5.3 & -8.2 & -1.7 & 4328 & 6.7 & 155.9 \\
\hline Rows $1-10$ & +8 & -16 & -5.56 & +2 & -8.2 & -2.8 & 1162 & 1.4 & 66.0 \\
\hline
\end{tabular}


Table 2

Erosion rates in different vineyards, based on data compiled from different sources

\begin{tabular}{|c|c|c|c|}
\hline Location & Observation time (yr) & Mean soil loss $\left(\mathrm{t} \mathrm{ha}^{-1} \mathrm{yr}^{-1}\right)$ & References \\
\hline Alsace, France & $>5$ & 32 & Litzler (1988) \\
\hline Champagne, France & $>1$ & 1,16 & Litzler (1988) \\
\hline Switzerland & $>1$ & $15-25$ & Litzler (1988) \\
\hline Languedoc, France & 40 & 5.5 & Litzler (1988) \\
\hline Champagne, France & 3 & 1.5 & Ballif (1990) \\
\hline Champagne, France & 3 & 0.6 & Ballif (1990) \\
\hline Aisne, France & 3 & 35 & Wicherek (1991) \\
\hline Duro, Portugal & 10 & 0.39 & Figueiredo and Ferreira (1993) \\
\hline Duro, Portugal & 10 & $1.1-2.8$ & Figueiredo and Ferreira (1993) \\
\hline New South Wales, Australia & 25 & 64.2 & Loughran and Balog (2006) \\
\hline New South Wales, Australia & 20 & 9.7 & Loughran and Balog (2006) \\
\hline Vosne-Romanée, France & 54 & 7.6 & Brenot et al. (2006) \\
\hline Aloxe-Corton, France & 50 & 14.9 & Brenot et al. (2006) \\
\hline Monthélie, France & 32 & 13.5 & Brenot et al. (2006) \\
\hline Monthélie, France & 20 & 23 & This study \\
\hline Monthélie, France & $20-50$ & $1.6-23$ & Brenot (2007) \\
\hline
\end{tabular}

identify linear structures characterized by a higher erosion rate at a higher spatial resolution (Fig. 7).

The SUM pattern (Fig. 7) is compared to the spatial erosion/ deposition pattern observed just after an individual rainstorm event (Fig. 9 A) in order to analyze the significance of the sciongraft unearthing. The sedimentary pattern has been mapped at $10-\mathrm{cm}$ resolution, and corresponds to the rill and fan networks formed in between the vine rows by overland flow processes. Rill and fan area have been interpolated at 1-m resolution to obtain a new map of erosion and sedimentation (Fig. 9B). This map shows that the patterns of erosion (rill) and sedimentation (fan) exhibit similar features to those observed on the simplified SUM map (Fig. 9C): (1) in the upper slope, a low rill-density domain correlates to a low erosion rate domain; (2) in the midslope, rill drainage density increases with the erosion rate; (3) in the lower slope, rills end with the deposition of large fans, analogous to the sedimentation occurring in the lower slope domain on the SUM map; (4) the two longest rills located on the left side, and draining through the plot, correlate to the intense erosion domain on the SUM map. At 10-cm resolution (Fig. 9A), it is impossible to correlate all the rills to the linear structures identified on the SUM map.

\section{Discussion}

\subsection{Erosion maps}

The good correlation between the two maps at 1-m resolution (Fig. 9B,C) suggests that SUM spatial patterning is significantly influenced by erosion and sediment transport occurring at the event scale. This interpretation is consistent with other short-term studies showing that high-intensity rainfall events are responsible for significant sediment export and topographic changes (Sirvent et al., 1997; MartínezCasasnovas et al., 2005), as well as with long-term studies that suggest a sediment yield dominated by catastrophic events (e.g., Kirchner et al., 2001). It thus becomes possible to interpret the spatial sediment distribution pattern of the SUM map as the result of the interplay between different erosion mechanisms acting over distinct spatial domains and at different time scales. Specifically, we suggest that the linear structures observed on the SUM map (Fig. 7) correspond to micro-rills observed in the event map. Over several years, these develop into larger ephemeral rills by recurrently conveying most runoff during rainfall events along the same path. The good correlation between the location of the intensively eroded domain and the rills located at the left side of the maps is evidence of the persistency of rill processes over 20 years, despite the frequent tillage erasing the ephemeral marks on surface. Conversely, the analysis of the two maps at a high-resolution scale shows that, although some rills present some temporal stability criteria, others disappeared during the upscaling from short to medium time scales, thus demonstrating the ephemeral behavior of some rills, already noted as "unsuccessful" rills by FavisMortlock (1998). We suppose that these temporary rills have been obliterated by smoothing processes operating at an intermediate time scale, i.e. $<20$ years. The mismatch between the two maps at high resolution could also be explained by anthropogenic control of sediment distribution, e.g., tillage prior to erosion.

From a spatial point of view, Fig. 9 illustrates that the behavior of the upper slope domain in the SUM map without the linear structures is similar to "the belt of no erosion" described by Horton (1945) at the event scale, although erosion occurs at low rates. The absence of the linear structures at both short-term and decennial scales, and the existence of a low erosion rate, suggest that the decennial upper slope erosion is dominated by splash and sheet-flow mechanisms. It is also possible to suggest that erosion in the mid-slope domain at the decennial scale is controlled by rill processes, as it is supported by the presence of several features commonly observed in rill-dominated systems: erosion rates that increase with slope length may be compared to rill "successfulness" (Favis-Mortlock, 1998).

The spatial patterning revealed by the SUM map documents a spatial partitioning of erosion mechanisms, i.e. sheet-flowdominated versus rill-dominated domains, and specifies the time scales at which they operate, i.e. smoothing processes versus ephemeral rill initiation and development processes. 
$\mathbf{A}$

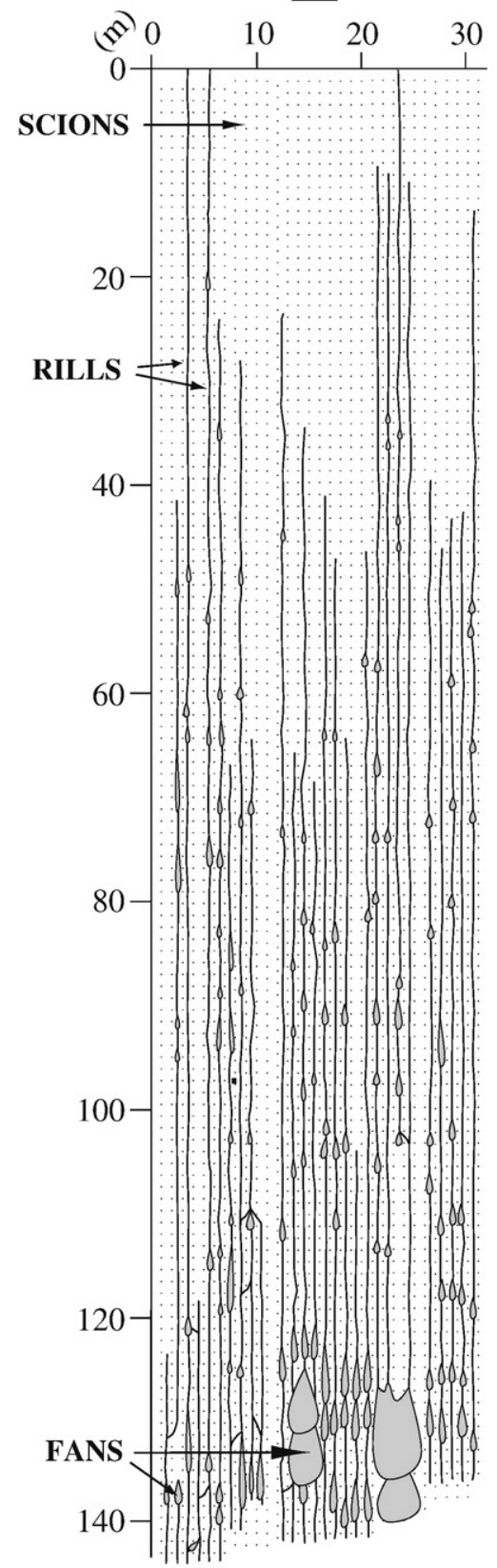

B

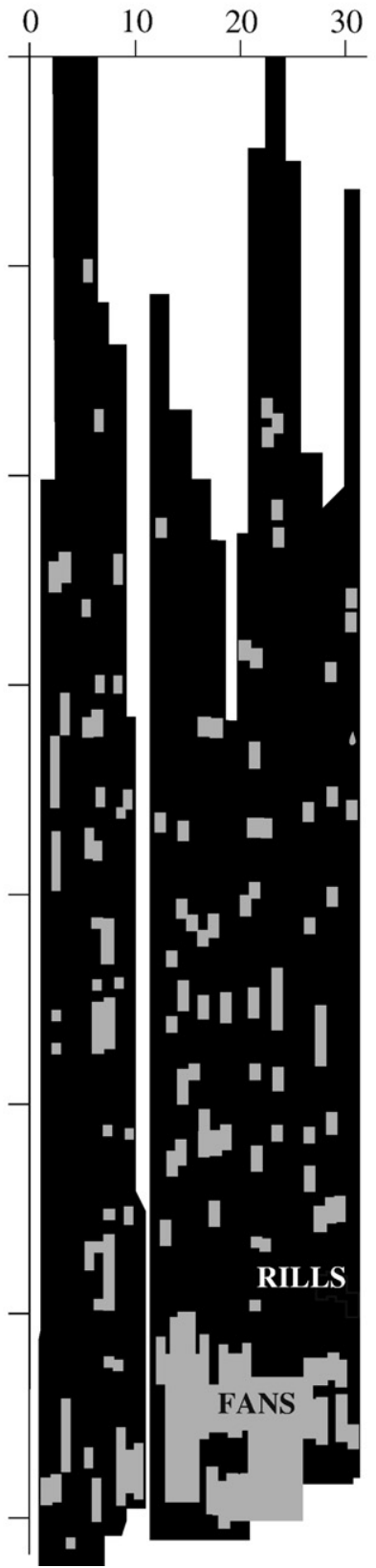

C

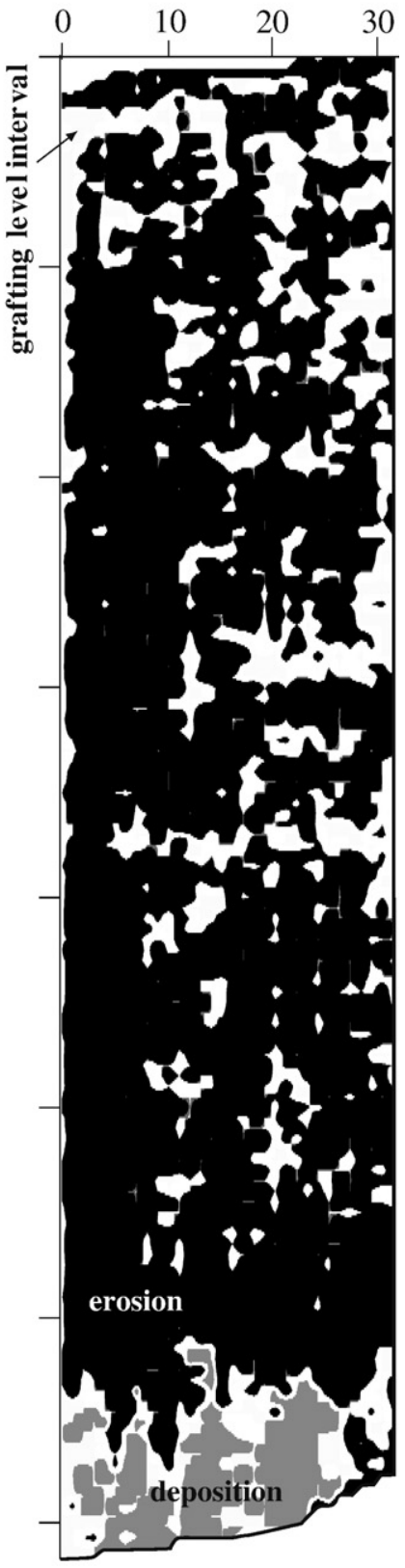

Fig. 9. Erosion maps of the studied plot. A) Map of rills and fans, developed during a single rainfall event. B) Simplified rill/fan map. Black pixels represent erosion; gray pixels represent deposition; white pixels represent by-pass. C) Simplified SUM map. Black pixels represent erosion; gray pixels represent deposition; white pixels represent SUM values within plantation error.

\subsection{SUM applications to vineyard areas}

The results of the SUM method application indicate that vine soils are very sensitive to runoff phenomena because of a particular land-use on steep hillslopes. The chosen example for this study reveals an intensive erosion dynamic that has been previously documented in many vineyards across the world (Kosmas et al., 1997; Krause et al., 2003; Hooke, 2006; Loughran and Balog, 2006), where erosion rates are much higher than soil production rates.
The initial results obtained from this study allow us to identify erosion processes and their effects on sediment redistribution over vine hillslopes. The good correlation between the two spatial erosion patterns associated with very different time scales, event versus decades, points to the importance of short-term effects from catastrophic overflow events on the cumulative erosion pattern at longer-time scales.

Several additional field studies would be helpful to establish a more accurate application of the SUM method. While this study has mainly focused on the cumulated effects of erosion 
processes, future studies may permit us to distinguish geomorphic episodes by associating root growth chronology (Fig. 5C) with major erosional and depositional events, as well as by analyzing adventitious root morphology (Carrara and Caroll, 1979; Strunk, 1997; Bodoque et al., 2005; Gärtner, 2007). Additional studies would be needed to explicitly quantify the interrow roughness volume, which is strongly dependent on the frequency of straddletractor tillage that tends to smooth out the rill pattern and compact the soil, as well as on vineyard maintenance practices such as rill infilling with sediment by vine growers (Brenot, 2007; Quiquerez et al., in press).

\section{Conclusion}

This paper presents a simple and inexpensive yet highly efficient method to quantify sediment yield from vine hillslopes based on scion-graft unearthing measurements (SUM) at decennial scale and 1-m resolution. By allowing the visualization of sediment distribution at 1-m scale, this approach offers new insights and possibilities for documenting erosion patterns and exploring erosion processes.

This quantitative study was performed at a plot representative of vineyards in Burgundy. The results suggest that the application of the SUM method to larger scales, e.g. catchment, and to other soil maintenance practices, e.g. non-ploughed plots, would complement this study by providing information on the effect of topographic parameters and various agricultural practices on soil losses in vineyards.

The results also indicate that the SUM method has a great potential in investigating the complex links between erosion rates and climates in this specific agricultural context, thus contributing to a better understanding of dynamic systems. The application of this method may also be helpful for land planners and soil scientists to develop soil conservation plans and to monitor the effectiveness of current strategies.

\section{Acknowledgments}

This work was included in the research program « RELIEFS », funded by the Centre National de la Recherche Scientifique (CNRS) and the Institut National des Sciences de l'Univers (INSU), Région Bourgogne, Rennes Métropole, and Bureau Interprofessionel des Vins de Bourgogne. We thank Carmela Chateau-Smith and Sarah Strano for their help with translation. We also thank Takashi Oguchi, Jon Pelletier, and an anonymous reviewer for their helpful comments, and T. Hewawasam for suggestions on an earlier version of the manuscript.

\section{References}

Alestalo, J., 1971. Dendrochronological interpretation of geomorphic processes. Fennia 105, 1-140.

Ballif, J.-L., 1990. Erosion dans le vignoble champenois: influence des techniques culturales (France). Cahiers ORSTOM, série Pédologie XXV, 151-156.

Battany, M.C., Grismer, M.E., 2000. Rainfall runoff and erosion in Napa Valley vineyards: effects of slope, cover and surface cover. Hydrological Processes $14,1289-1304$.
Boardman, J., Poesen, J., 2006. Soil Erosion in Europe. Chichester, Wiley. Bodoque, J.M., Diez-Herrero, A., Marin-Duque, J.F., Rubiales, J.M., Godfrey, A., Pedraza, J., Carrasco, R.M., Sanz, M.A., 2005. Sheet erosion rates determined by using dendrogeomorphological analysis of exposed tree roots: two examples from Central Spain. Catena 64, 81-102.

Boix-Fayos, C., Martínez-Mena, M., Arnau-Rosalén, E., Calvo-Cases, A., Castillo, V., Albaladejo, J., 2006. Measuring soil erosion by field plots: understanding the sources of variation. Earth-Science Reviews 78, 267-285.

Brenot, J., 2007. Quantification de la dynamique sédimentaire en contexte anthropisé: l'érosion des versants viticoles de Côte d'Or. Unpublished Ph.D. Thesis, Université de Bourgogne, Dijon.

Brenot, J., Quiquerez, A., Petit, C., Garcia, J.-P., Davy, P., 2006. Soil erosion rates in Burgundian vineyards. Bolletino della Società Geologica Italiana, Volume Speciale 6, 169-174.

Buoncristiani, J.F., Petit, C., Campy, M., Bossuet, G., Richard, H., 2002. Quantification de l'ablation d'un bassin versant marno-calcaire alpin durant le Petit Age Glaciaire par l'étude d'un système lacustre (cas du lac du « Claps » de Luc-en-Diois, Drôme, France). Geodinamica Acta 15, 103-111.

Carrara, P.E., Caroll, T.R., 1979. The determination of erosion rates from exposed tree roots in the Piceance Basin, Colorado. Earth Surface Processes 4, 407-417.

Danzer, S.R., 1996. Rates of slope erosion determined from exposed roots of ponderosa pine at Rose Canyon Lake, Arizona. In: Dean, J., Meko, D.M., Sewtnam, T.W. (Eds.), Tree Rings, Environment, and Humanity. Radiocarbon 1996, Proceedings of the International Conference, Tucson, Arizona, 17-21 May 1994. Department of Geosciences, The University of Arizona, Tucson, pp. 671-678.

Dion, R., 1959. Histoire de la Vigne et du Vin en France. Paris, Flammarion.

Dunne, T., Dietrich, W.E., Brunengo, J., 1978. Recent and past erosion rates in semi-arid Kenya. In: Zeitschrift für Geomorphologie N. F. Supplement Band 29, 130-140.

Eardley, A.J., Viavant, W., 1967. Rates of denudation as measured by Bristlecone Pines. Utah Geological and Mineralogical Survey, Special Studies, vol. 21. Cedar Breaks, Utah.

Einsele, G., Hinderer, M., 1997. Terrestrial sediment yield and the lifetimes of reservoirs, lakes, and larger basins. Geologische Rundschau 86, 288-310.

Favis-Mortlock, D., 1998. A self-organizing dynamic systems approach to the simulation of rill initiation and development on hillslopes. Computers and Geosciences 24, 353-372.

Figueiredo, T., Ferreira, A.G., 1993. Erosão dos solos em vinha de encosta na região do Douro, Portugal. Actas do XII Congresso Latinoamericano da Ciência do Solo, SECS (19-26 September Salamanca, Spain), pp. 79-88.

Fournier, F., 1972. Les aspects de la conservation des sols dans les différentes régions climatiques et pédologiques de l'Europe. Sauvegarde de la Nature, vol. 6. Conseil de l'Europe, Strasbourg.

Galet, P., 1993. Précis de Viticulture, 6ème édition. Lavoisier, Paris.

Garrier, G., 1989. Le Phylloxera. Paris, Albin Michel.

Gärtner, H., Schweingruber, F.H., Dikau, R., 2001. Determination of erosion rates by analyzing structural changes in the growth pattern of exposed roots. Dendrochronologia 19, 81-91.

Gärtner, H., 2007. Tree roots - methodological review and new development in dating and quantifying erosive processes. Geomorphology 86, 243-251.

Goudie, A., 2005. The Human Impact on the Natural Environment, 6th Ed. Oxford, Blackwell.

Hewawasam, T., von Blanckenburg, F., Schaller, M., Kubik, P., 2003. Increase of human over natural erosion rates in tropical highlands constrained by cosmogenic nuclides. Geology 31, 597-600.

Hilfiker, C., Dominik, J., 1989. Traçage de l'érosion des sols par des méthodes radio-isotopiques. Cahiers de la Faculté des Sciences de l'Université de Genève 19, 9-18.

Hooke, J.M., 2006. Human impacts on fluvial systems in the Mediterranean region. Geomorphology 79, 311-315.

Horton, R.E., 1945. Erosional development of streams and their drainage basins: a hydrophysical approach to quantitative morphology. Bulletin Geological Society of America 56, 275-370.

Kirchner, J.W., Finkel, R.C., Riebe, C.S., Granger, D.E., Clayton, J.L., King, J.G., Megahan, W.F., 2001. Mountain erosion over 10 yr, 10 k.y., and 10 m.y. time scales. Geology 29, 591-594. 
Kosmas, C., Danalatos, N., Cammeraat, L., Chabart, J., Diamantopoulos, J., Farand, R., Gutierrez, L., Jacob, A., Marques, H., Martínez-Fernandez, J., Mizara, N., Moustakas, N., Nicolau, J., Oliveros, C., Pinna, G., Puddu, R., Puigdefabregas, J., Roxo, M., Simao, A., Stamou, G., Tomasi, N., Usai, D., Vacca, A., 1997. The effect of land use of runoff and soil erosion rates under Mediterranean conditions. Catena 29, 45-59.

Krause, A.K., Loughran, R.J., Kalma, J.D., 2003. The use of caesium-137 to assess surface soil erosion status in a water-supply catchment in the Hunter Valley, New South Wales, Australia. Australian Geographical Studies 41, 73-84.

Lal, D., 1991. Cosmic ray labeling of erosion surfaces: in situ nuclide production rates and erosion models. Earth and Planetary Sciences Letters 104, 424-439.

LaMarche Jr., V.C., 1968. Rates of slopes degradation as determined from botanical evidence. White Moutains, California. USGS Professional Paper 32, 341-377.

Le Bissonnais, Y., Thorette, J., Bardet, C., Daroussin, J., 2002. L'érosion hydrique des sols en France. Rapport INRA-IFEN.

Litzler, C., 1988. Le ruissellement et l'érosion des sols dans le vignoble de Saône-et-Loire. C.A, D.D.A et C.R. de Saône-et-Loire.

Loughran, R.J., Balog, R.M., 2006. Re-sampling for soil-caesium-137 to assess soil losses after a 19-year interval in a Hunter Valley Vineyard, New South Wales, Australia. Geographical Research 44, 77-86.

Martens, D.M., 1993. Hydrologic inferences from tree-ring studies on the Hawkesbury River, Sydney, Australia. Geomorphology 8, 147-164.

Martínez-Casasnovas, J.A., Ramos, M.C., Ribes-Dasi, M., 2002. Soil erosion caused by extreme rainfalls events: mapping and quantification in agricultural plots from very detailed digital elevation models. Geoderma $105,125-140$.

Martínez-Casasnovas, J.A., Ramos, M.C., Ribes-Dasi, M., 2005. On-site effects of concentrated flow erosion in vineyard fields: some economics implications. Catena 60, 129-146.

Meade, R.H., 1988. Movement and storage of sediment in river system. In: Lerman, A., Maybeck, M. (Eds.), Physical and Chemical Weathering in Geochemical Cycles. Kluwer, Dordrecht, pp. 165-179.

Morgan, R.P.C., 2005. Soil Erosion and Conservation, 3rd Ed. Oxford, Blackwell.

Quine, T.A., Walling, D.E., 1991. Rates of soil erosion on arable fields in Britain: quantitative data from caesium-137 measurements. Soil Use and Management 7, 169-176.
Quiquerez, A., Brenot, J., Petit, C., Garcia, J.-P., in press. Soil degradation caused by a high-intensity rainfall event: implications for medium-term soil sustainability in Burgundian vineyards. Catena.

Ritchie, J.C., Nearing, M.A., Nichols, M.H., Ritchie, C.A., 2005. Patterns of soil erosion and redeposition on Lucky Hills Watershed, Walnut Gulch Experimental Watershed, Arizona. Catena 61, 122-130.

Rommens, T., Verstraeten, G., Bogman, P., Peeters, I., Poesen, J., Govers, G., Van Rompaey, A., Lang, A., 2006. Holocene alluvial sediment storage in a small river catchment in the loess area central Belgium. Geomorphology 77, 187-201.

Sirvent, J., Desir, G., Gutierrez, M., Sancho, C., Benito, G., 1997. Erosion rates in badland areas recorded by collectors, erosion pins and profilometer techniques (Ebro Basin, NE-Spain). Geomorphology 18, 61-75.

Stroosnijder, L., 2005. Measurement of erosion: it is possible? Catena 64, $162-173$.

Strunk, H., 1997. Dating of geomorphological processes using dendrogeomorphological methods. Catena 31, 137-151.

Sweetkind, D.S., Blackwell, D.D., 1989. Fission-track evidence of the Cenozoic thermal history of the Idaho batholith. Tectonophysics 157, 241-250.

Van Der Perk, M., Jetten, V., 2006. The use of a simple sediment budget model to estimate long-term contaminant export from small catchments. Geomorphology 79, 3-12.

Vandaele, K., Poesen, J., Govers, G., Wesemael, B., 1996. Geomorphic threshold conditions for ephemeral gully incision. Geomorphology 16, $161-173$.

Verstraeten, G., Poesen, J., 2001. Factors controlling sediment yield from small intensively cultivated catchments in a temperate humid climate. Geomorphology 40, 123-144.

Wainwright, J., Parsons, A.J., Michaelides, K., Powell, M., Brazier, R., 2003. Linking short and long term soil erosion modelling. In: Lang, A., Hennrich, K., Dikau, R. (Eds.), Long Term Hillslope and Fluvial System Modelling. Springer-Verlag, Berlin, pp. 37-51.

Wicherek, S., 1991. Viticulture and soil erosion in the north of Parisian Basin; example: the Mid Aisne Region. Z. Geomorph. N.F. Suppl.-Bd. 83, 115-126.

Wischmeier, W.H., Smith, D.D., 1978. Predicting rainfall erosion losses: guide to conservation planning. Agricultural Handbook, vol. 282. UDSA, Washington DC. 